\title{
Reklama İçerden Bir Bakış
}

\author{
Mete Çamdereli (Prof. Dr.) \\ İstanbul Ticaret Üniversitesi Illetişim Fakültesi \\ mcamdereli@ticaret.edu.tr \\ Başvuru Tarihi: 15.02.2021 \\ Yayına Kabul Tarihi: 01.04.2021 \\ Yayınlanma Tarihi: 30.07.2021 \\ https://doi.org/10.17680/erciyesiletisim.880683 \\ Öz
}

Reklam tarihiyle ilgili çalışmalara çok az rastlanıyor. $\mathrm{Bu}$ temel kaygıdan hareketle bu çalışmanın amacı, reklamın bir belge niteliğiyle dönem okumasına imkan verip vermeyeceğidir. Bunu anlayabilmek için reklam hakkında çeşitli yerlerde yazılmış yazılara değil de salt reklam amacıyla Türkiye'de çıkan gazete ve dergilere ve onların da sadece sunuş yazılarına odaklanmak tercih edildi. Çeyrek yüzyıla yayılan ve ilk sayıları erişilebilir durumdaki on reklam gazete ve dergisi inceleme nesnesi olarak seçildi. Çalışma, zamansal olarak 1948-1974 yıllarına karşılık gelen yirminci yüzyılın üçüncü çeyreğiyle sınırlanmış oldu.

Bu amaç, kapsam ve sınırlılık çerçevesinde, reklam gazetelerinin ilk sayılarında yer alan sunuş yazılarının okunması yoluyla dönemin reklama ilişkin söylemi betimlenmiș, aynı zamanda reklamın dönemsel yapı ve işleyişi ortaya çıkmış oldu.

Anahtar Kelimeler: Reklam Tarihi, Reklam Gazetesi, 1948-1974 Dönemi, Reklam Çözümlemesi. 


\title{
An Inside Look at The Advertisement
}

\author{
Mete Çamdereli (Prof. Dr.)
}

Distanbul Commerce University Faculty of Communication mcamdereli@ticaret.edu.tr

Date Received: 15.02 .2021

Date Accepted: 01.04.2021

Date Published: 30.07.2021

https://doi.org/10.17680/erciyesiletisim.880683

\section{Abstract}

Studies on the history of advertising are rare. Based on this basic concern, the purpose of this study is whether the advertising will allow reading a period as a document. To understand this, it was preferred to focus on the newspaper and magazine advertising in Turkey which was published only for advertising. Not just articles written about advertising in various places. And also, it was preferred to focus on their presentation articles. Ten commercial newspapers and magazines were selected as the object of study, which the first issues of them are accessible and span a quarter century. The work is limited to the third quarter of the twentieth century, which as time span corresponded to the years 1948-1974.

Within the framework of this purpose, scope and limitation, the advertising discourse of the period was interpreted by reading the presentation articles in the first issues of the advertising newspapers, and at the same time, the periodic structure and functioning of the advertisement was revealed.

Keywords: Advertisement History, Advertisement Newspaper, Term Between 19481974, Advertisement Analysis. 


\section{Giriş}

Reklam tarihi, reklamın gelişim seyrini betimlemeye çalışırken bir yandan da iktisat tarihi, sosyoloji ya da siyaset bilimi gibi kimi alanları da doğrudan ilgilendirecek izler bırakır. Reklam tarihine dönük okumalar, temeli iletişim olan bir yelpazede sosyal değişmeden ekonomik parametrelere dek birçok konu hakkında bilgi ve fikir vericidir. Belge nitelikli okumalara da imkan veren reklamlar dönemlerinin ticari, iktisadi ve siyasi hayatına ister istemez ayna tutarlar. Kültürel bir markanın kuruluş ve gelişme dönemleri ya da siyasal bir partinin dönemsel mevcudiyeti ve icraatı reklamlardan kolaylıkla anlaşılabilir.

$\mathrm{Bu}$ çalışmanın amacı, reklamın tarihsel incelemelerinin işgal ettiği alanları belirlemek değil, reklamın bizzat belge olmasının ortaya konması da değil, daha çok onun hakkında yazılanların da bir belge olup olmayacağını ve bir belge niteliğiyle dönem okumasına imkan verip vermeyeceğidir. Bunu anlayabilmek için reklam hakkında çeşitli yerlerde yazılmış yazılara değil de salt reklam amacıyla Türkiye'de çıkan gazete ve dergilere ve onların da sadece sunuş yazılarına odaklandık. Çeyrek yüzyıla yayılan ve ilk sayıları erişilebilir durumdaki on reklam gazete ve dergisini inceleme nesnesi olarak seçtik. Çalıșmamızı, böylece, zamansal olarak 1948-1974 yıllarıyla, deyim yerindeyse savaș sonrası erken dönem ile, ya da yirminci yüzyılın üçüncü çeyreğiyle sınırlamış olduk.

Bu amaç, kapsam ve sınırlılık çerçevesinde, reklam gazetelerinin ilk sayılarında yer alan sunuş yazılarının okunması yoluyla dönemin reklama ilișkin söylemi betimlenmeye ve aynı zamanda reklamın dönemsel yapı ve işleyişi anlaşılmaya çalışılacaktır. Çıkarken dillendirilen amaç ve nedenleri içkin sunuş yazılarının reklamın o dönemdeki söylemsel izini sürme imkanı vereceği, dönemin reklam anlayıșını, döneme özgü reklama dönük anlam haritasını ortaya çıkaracağı öngörülebilirdir.

Kimi epey uzun kimi kısa bir başlangıç ya da giriş niteliğindeki sunuşlar, yöntemsel olarak yalın bir söylem çözümlemesine tabi tutulurken, öncelikle her metin kendi içinde okunacak, sonunda metinlerarası benzerlik ve karşıtlıklar saptanarak bir çıkarsamaya varılmaya çalışılacaktır. Bu yapılırken birini diğerinden ayıran ya da birini diğerine yaklaştıran söylem çizgileri de belirginleştirilmiş olacaktır. Böylelikle her metnin söyleminde içkin bulunan reklama ilişkin kavramsallaştırmalar belirlenirken, sonunda bütüncül olarak değerlendirilecek metinler, reklamın reklam gazetelerinden dönemsel görünümünü ve dönemin reklama bakışını betimleyecektir. Böylelikle reklamdan hareketle bir dönem okuma ön çalışması ya da bir döneme reklamın penceresinden kısa bir bakış gerçekleşmiş olacaktır.

Önce, söylemine odaklanacağımız inceleme nesnesinin, içinde yer aldığı reklam dergigazeteleri hakkında kısa bir bilgi verelim, ardından çözümlemeye geçebiliriz.

\section{Reklam Gazeteciliği}

Türkiye'de bilinebilen ilk reklam örneği 17. yüzyıl sonları olarak tarihleniyor ${ }^{1}$. O gün bugündür reklam adına önemli gelişmeler yaşanmış, çeşitli yayın, tasarım ve mecra uygulamaları deneyimlenmiştir. Reklam artık yaygın biçimde bilinmektedir ve çeşitli gazete, dergi ve ticari yayınlarda çokça görünür hale gelmiștir. Reklamın bu gelişim serüvenine paralel olarak, reklamların çok daha yoğun biçimde bir araya geldiği ve topluca görülebildiği reklam gazeteleri de söz konusu olmuştur.

Salt reklam yayıncılığı amacıyla, Londra'da 17.yüzyılda The Publick Adviser ile ortaya çıkan (Çamdereli, Varlı, 2009, s.13) reklam gazete ve dergileri 19. yüzyılın ikinci yarısından itibaren ülkemizde de görülmeye başlanmış, özellikle II. Meşrutiyet'in ilanıyla birlikte 
iyiden iyiye belirginleșmiștir. Bir yayın tipi olarak benimsenen reklam gazete ve dergileri, dönemin çeşitli dillerde çıkan siyasi, iktisadi, mizahi, dini, edebi, mahalli gazeteleri arasında, sayfalarında sadece reklam yayınlamaya çalışan yayınlar olarak matbuatta yerlerini almışlardır. Türkiye'nin ilk reklam gazeteleri arasında İlan, Küçük İlanat, Reklam, Tacir, Şark gibi -genellikle çokdilli- gazete ve dergiler sayılabilir.

Cumhuriyet dönemine gelindiğindeyse, reklamın silkinme ve toparlanma yıllarının ardından modernleşme dönemine geçiş adımlarına tanıklık edilmiştir. Reklam adına yapılan hemen her uygulamanın, gelişen baskı teknolojileriyle beraber artık daha gelişkin tasarım ve mecra modelleri ortaya çıkmaya başlamıştır. Reklamların tek elden bir mecra ile hedef kitlelere ulaştırılması bu kaygının tezahürüdür. Reklam gazeteleri hedef kitleleri doğrudan reklamveren ve ürün/hizmetle buluşturan bir mecra olarak dikkat çekicidir; geçmişten gelen tasarım ve mecra arayışının bir uzantısı olarak ortaya çıkarlar. Reklam gazeteciliğinin, yukarıda isimleri anılan gazete ve dergiler göz önüne alınınca, artık bir deneyimi vardır ve reklam gazeteleri de o deneyim üzerine inşa edilmişlerdir. Ancak dönem değişmiş, baskı teknikleri ve formatları değişmiş, özellikle Amerikan reklamcılığı örnek modelleme olarak öne çıkmaya başlamıştır². Reklam gazeteciliği de bu tarz bir gelişime ayak uydurmaya çalışmıştır.

Reklam gazeteciliği, kabaca, sağlık, ekonomi, spor, elektronik, moda ve dekorasyon gibi, sınırları ve konuları iyice belirlenmiş ve yalnızca belirli bir izleyici, okuyucu ve dinleyici kitlesine dönük olarak daraltılmış bir ihtisas yayıncılığıdır. Daraltılmış alandan bilgilenme talep eden ve ilgilendiği alan ile ilgili bütün reklamları bir arada görme imkanı bulan belirgin hedef kitleleri memnun edebilecek kalitede yayıncılık anlayışıyla öne çıkar. Bugün de günümüz mecralarında evrilerek yaşamını sürdüren reklama dönük ihtisas yayıncılığı; kimi zaman reklam yoğunluklu yayın yapan dijital platformlarda kimi zaman yeterince ayrışmış sektöriyel yayınlarda kendine yer bulabilmekte, kazandığı birikim ve deneyimi yeni mecralarda geliştirebilmektedir. (Ayrıntılı bilgi için bkz. Çamdereli, Varlı, 2009, s.12-16).

Çözümlenecek inceleme nesnesi olarak masaya yatıracağımız reklam gazete ve dergilerinin özellikle ülkemizdeki görünümüyle ilgili verdiğimiz bu kısa bilginin ardından çalışmanın çözümleme kısmına geçebiliriz.

\section{Reklamın Bir Dönemini Okumak}

Reklamın bir dönemini okuyabilmek ve aynı zamanda dönemin reklama bakışını belirleyebilmek için, yirminci yüzyılın üçüncü çeyreğini kapsayan zaman diliminde ${ }^{3}$, reklam gazete-dergilerinin erişilebilir durumdaki ilk sayılarında yer alan on sunuş yazısını inceleme nesnesi olarak aldık. Yayın yıllarını ve yerlerini de bir fikir vermek üzere başlıklara ekledik. İnceleme nesnemizi belirleyen sunuş yazıları, girişte de belirttiğimiz gibi, izlediğimiz yöntemin imkanları çerçevesinde önce kendi içinde ayrı ayrı okumaya, anlamaya, anlamlamaya alınacak, sonunda topluca masaya yatırılarak kavramsal bir çlkarsamaya gidilecektir.

\section{Çözümleme Yöntemi}

Çözümleme yöntemi olarak seçtiğimiz söylem (ve/ya da metin) çözümlemesi temel olarak dilin, dilsel kurgunun ya da buradaki durumda metnin iletişim işlevini belirleyici ve betimleyici bir özellik taşır. İletişim işlevleri ve kavramsal göndergeleri belirlenecek metinler ayrı ayrı ve topluca okunmaya çalışılırken betimsel bir çıkarsamaya varmak 
da söz konusu olacaktır. Bir başka deyişle burada dar kapsamlı olarak yapılacak çözümlemenin betimsel bir söylem çözümlemesi olacağı açıtır.

Sunuş metinlerinin söylemini çözümlemek ve anlam alanını betimleyebilmek için iki düzeyli bir işlem yapılacaktır. Metinler ayrı ayrı okunurken önce söylemin belirim biçimi ya da yüzeysel görünümü -söylemsel yüzey başlığı altında- eksiltili olarak belirtilecek, ikinci düzeyde söylemin kavramsal yapı ve işleyişi -söylemsel yargı başlığı altındaana çizgileriyle belirlenecek. Bunu yapmakla birinci düzeyde reklama ilişkin olarak 'metinde ne var?'a, ikinci düzeyde yine reklama ilişkin olarak 'metin ne söylüyor?'a yanıt aranmış olacak.

Sonuçta gerçekleştirilecek toplu okumada her metinden ikinci düzeyde çıkan yargılar bir araya getirilecek ve nihai bir çıkarsama elde edilmeye çalışılacaktır. Tüm bu işlemler yapılırken metni kuran dilsel verilere tutunulacağı ama çözümleme işleminin kısa tutulabilmesi için sözdizimsel, sözbilimsel, üslupbilimsel, edimbilimsel, dilbilgisel vb. ayrıntılara girilemeyecektir.

Söylem çözümlemesinde izlenecek söylem basamakları inceleme nesnesinin tür ve kurgusal yapısı doğrultusunda, çözümlemecinin tercihlerine göre şekillenir. Söylem içkin metinlerin dilsel yapısı metinsel ilişkilerden beslendiğinden söylem çözümlemesinin metin çözümlemesi ya da söylem dilbiliminin metindilbilim olarak anılması mümkündür (Örneğin bkz. Rifat, 1998, Cilt 2, s.190,191). Söylem ile ilgili kimi zaman yaşanan kavram karışıklığı büyük ölçüde söylemin kavramsallaştırılmasındaki tek yanlı tikel yaklaşımlardan, -dilbilimsel söylem, göstergebilimsel söylem, Foucaultcu ya da Deridacı söylem, eleștirel söylem gibi- kaynaklanır. Bu durum doğal olarak tümü kapsayıcı büyük metne karşılık gelen söylemin tipolojik özelliklerinden -hukuk söylemi, tıp söylemi gibi- bağımsız değerlendirilmesine ve kimi zaman da salt konuşucunun ürettiği söz ile eşitlenmesine yol açar. Tekil bir yaklaşım üzerinden bakılınca söylem her zaman tikel ve eksiltilidir. Halbuki metin, daha çok sınırları belirlenmiş bir söylem gibi algılanırsa mezkur karışıklık büyük ölçüde giderilmiş olur. Metinler cümleyi aşan bildik bütüncül yapılardır. Söylemse bir metnin ürettiği kavramsallaştırmayı içkin kuşatıcı dilsel yapılar ya da metinlerle üreyen ve bütünselleşen dilsel gerçekleşmelerdir. Dilsel gerçekleşme her metnin ve/ya da metni kuran her birimin bir söylem ürettiğini ifade eder. Bu durumda metin ayrıntılandırılabilir ve metnin yapısal örüntüsü ayırıcı ve/ya da birleştirici birimler olarak ele alınmak imkanına kavuşur. Kabaca, söylem metni kuşatır ve metnin neresinde aranıyorsa oraya bakmak ya da orada/n derinleşmek yeterlidir. Biz de burada bunu yaptık; her bir kurucu ayrıntıyı söylem içkin bir metin gibi kavradık ve söylem düzeylerini bu bakıș açısıyla, yani birbirinden ayrılamaz anlamsal göndergeler yüklenmiş söylemsel yapılar olarak belirledik. Çünkü "her söylemin ardında bir anlam evreni bulunduğunu söylemek hiç abartılı olmaz" (Yücel,1999, s.11). Söylem çözümlemesi, öyleyse, o büyük anlam evreni içindeki söylem basamaklarını tırmanmaktan, söylemi kuran birimleri baştan başa geçmekten, deyim yerindeyse metinsel söylembirimlerin göndergesel izini sürmekten ibarettir (Bu konuda ayrıntılı bilgi için bkz. Evre, 2009, s.107-152).

Söylem çözümlemesinin imkan ve sınırlarını kısaca belirledikten sonra, yöntemsel tutum olarak yukarıda belirlediğimiz basamaklar eşliğinde çözümleme işlemini gerçekleştirebiliriz. 


\section{Çözümleme İşlemi}

Bir ön çalışmaya nispet eden buradaki çözümleme işleminde atılacak adımları belirginleștirdikten sonra, bütünce olarak tercih edilen on reklam gazete-dergisinin iki düzeyli söylem okumasını, dönemin ilk yayını Reklam-Satış'tan başlayarak tarihsel sıralamaya göre gerçekleştirebiliriz.

- Reklam - Satış (1948, İstanbul)

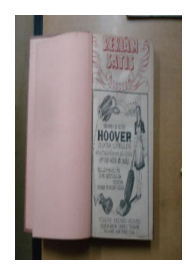

Söylemsel yüzey: Reklam Satış Dergisinin beș cümlelik sunuş yazısı 'Çıkarken' başlı̆̆ı taşıyor ve ilk cümlede reklama verdikleri önem vurgulanıyor. Ülkemizde reklamın önemine dair çalışmaların azlığı ima ediliyor. Derginin bu kaygıyla çıktığı, reklamcılık usullerinin işletileceği, kitlelere yayılacağı ve bu konuda kararlı oldukları belirtiliyor. Bunu yapmakla işletmelere hizmet etmiş olacakları ve hizmet üretebilmek için de reklam desteği bekledikleri dile getiriliyor.

Söylemsel yargi:

- Ticari ilerleme doğrudan reklamla ilişsilidir.

- Reklamın öneminin vurgulanması kaçınılmazdır.

- Reklamın önemi geniş kitlelere anlatılmalıdır.

- İşletmelere reklam hizmeti ulaştırılabilmesi için işletmelerin de reklam vermeleri şarttır.

- Reklam Gazetesi (1948, İzmir)

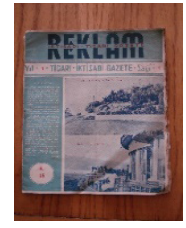

Söylemsel yüzey: Reklam Gazetesi'nin sekiz cümlelik sunuş yazısı 'Niçin Çıkıyoruz' başlı̆̆ı taşıyor ve önce reklamın önemi vurgulanıyor. Reklamın insanları ve milletleri birbirine yaklaştırdığı ve memleketleri refaha götürdüğü telaffuz ediliyor. Memleketimizde reklam yayını yapılmadığı belirtiliyor. Memleket aleyhine propagandalar yapıldığı ve bunun önüne geçilmesi gerekliliğinin altı çiziliyor.

Söylemsel yargi:

- Reklam ticaret, sanayi ve ekonomi için çok önemlidir.

- Reklam insanları ve milletleri birbirine yaklaştırır.

- Reklam memleketleri refaha götürür.

- Reklam ile ilgili yayın yapmak gereklidir.

- Reklam, memleket aleyhine yapılan olumsuz propagandaları da engelleyicidir. 
- Türkiye Reklam ve Sanat Ansiklopedisi (1948, İstanbul)

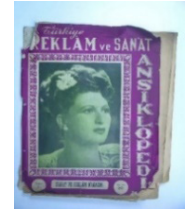

Söylemsel yüzey: Türkiye Reklam ve Sanat Ansiklopedisi'nin bir sayfayı aşan uzun sunuş yazısı, 'Çıkarken' başlı̆̆ taşıyor ve sanat ile ilgili bilgi verdikten sonra öncelikle sanatkarın reklama ihtiyacı olduğu, sanatın reklamsız olmayacağı vurgulanıyor. Okuyucu ve seyircinin reklamını gördüğü esere uzandığını, eleştirilere dikkat kesildiğini, eseri ancak eleştirmenin reklamından sonra okuduğunu belirtiyor. Eleştirmenin iyi eserlerin reklamını yaparak okurun zaman kaybını engelleme fonksiyonunu üstlendindiğini ve zaten üstlenmesi gerektiğini ifade ediyor. Sonunda, reklam ve sanatın birbirinden ayrılamayacağını, sanatkarane reklam ile reklamı yapılan sanatın yayın yoluyla gelişeceğini ilave ediyor.

Söylemsel yargi:

- Sanatın da sanatçının da reklama ihtiyacı vardır.

- Okurlar eleştirmenlerin yaptıkları reklamları okuduktan sonra kitap okurlar.

- Eleştirmenin görevi reklam yaparak okura zaman kazandırmak, iyi eserleri göstermektir.

- Reklam ve sanat birbirini kucaklar.

- Reklam sanatı ve sanat reklamı ancak yayın yaparak gelişir.

- İlan ve Reklam (1949, İstanbul)

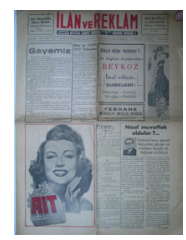

Söylemsel yüzey: İlan ve Reklam gazetesinin ondört cümlelik sunuş yazısı 'Gayemiz' başlığı taşıyor ve önce sırf ilan ve reklam için çıktıklarını, mütevazi bir ücretle satılacağını ve reklamverene hitaben geniş bir halk kitlesine ulaşacak düzeyde bir tiraj umulduğunu belirtiyor. Reklamcılığın Avrupa ve Amerika ayarına çıkarılması için gerekli donanım ve insan kaynağına sahip olunduğu vurgulanıyor. Malların reklam verilerek kısa sürede ve iyi bir fiyatla satılabileceği de ifade ediliyor.

Söylemsel yargı:

- Reklamveren için geniş halk kitlelerine ulaşmak önemlidir.

- Reklamcilık ilkel durumundan kurtulmalıdır.

- Reklamveren reklam vermelidir.

- Reklam, ürünlerin satılması için gereklidir. 
- Resimli Reklam (1949, Adana)

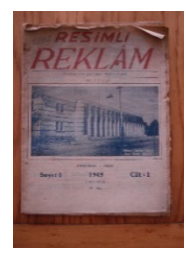

Söylemsel yüzey: Resimli Reklam dergisinin bir sayfalık sunuş yazısı 'Niçin Çıkıyoruz' başlığı taşıyor ve kişilerin kalkınmasının tanınmakla mümkün olduğunu, bir girişimin başarısının büyük ölçüde reklam ve propagandayla ilişkili olduğunu belirtmekle başlıyor. Reklam ve propagandaya henüz bir ihtiyaç olarak iltifat edilmediğini söylüyor. Reklam ve propagandanın Amerika'da gelişkin olduğu ve bir kuruluşun sermayesinin büyük kısmını reklam ve propagandaya ayırdığı ifade ediliyor. Ülkemizde reklam ve propagandaya yapılan masrafın gereksiz olarak düşünüldügünün, halbuki ona yapılan yatırımın kısa sürede geri döndüğünün, reklam ve propagandanın bir kuruluşun temel ihtiyacı olduğunun altı çiziliyor.

Söylemsel yargi:

- Reklam ve propaganda girişimin ve girişimcinin başarısında büyük pay sahibidir.

- Reklam ve propaganda Amerika'da son derece gelişmiştir.

- Reklam ve propagandaya henüz ihtiyaç gözüyle bakılmıyor, boşa masraf olarak değerlendiriliyor.

- Reklam ve propaganda harcamaları gereksiz değildir, tersine kuruluşlar için temel ihtiyaçtır.

- Türkiye Reklam Mecmuası (1955, Ankara)

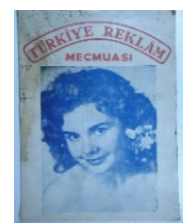

Söylemsel yüzey: Türkiye Reklam Mecmuası'nın dokuz cümlelik sunuş yazısı 'Çıkarken' başlığı taşıyor ve önce rekabetin reklamla sıkı ilişkisi olduğunu vurguluyor. Rekabetin tanımak ve tanıtmak silahını elinde tuttuğunu belirtirken, piyasaya sunulan ürünlerin sürümü ve firmaların şöhretlerini arttırmak için reklamın kesinlikle ihtiyaç olduğunu dillendiriyor. Reklamın ürüne talep arttıracağını ifade ediyor.

Söylemsel yargı:

- Reklam piyasa rekabeti için son derece önemlidir.

- Reklam ürünlerin piyasaya sunulmasını ve ürünlere talebin artmasını sağlar.

- Reklam firmaları şöhretini artırır. 
- Reklam Gazetesi (1959, İzmir)

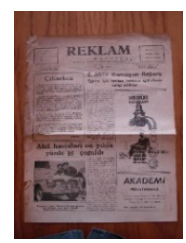

Söylemsel yüzey: Reklam Gazetesi'nin yedi cümlelik sunuş yazısı 'Çıkarken' başlığı taşıyor ve ekonomik faaliyete yardımcı olan reklam ve propagandanın günden güne önem kazandığını belirtiyor. Reklam ve propagandanın alış verişi verimli ve değerli hale getirdiğini, ihtiyaç duyulan bir maddenin teminini süratlendirdiğini ifade ediyor.

Söylemsel yargı:

- Reklam ve propaganda ekonomik faaliyette giderek önem kazanıyor.

- Reklam ve propaganda alışverişi verimli hale getirir.

- Reklam ve propaganda bir hizmeti değerli hale getirir.

- Reklam ve propaganda bir ihtiyacın hızla karşılanmasını mümkün hale getirir.

- Reklam Magazin, (1961, Ankara)

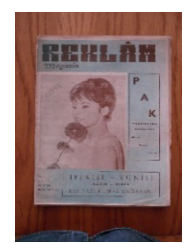

Söylemsel yüzey: Reklam Magazin'in sekiz cümlelik sunuş yazısı 'Sayın Okuyucularımız' hitabıyla başlıyor ve çeşitli konulara yer veren yazıların yanında derginin daha çok reklam işlerine ayrılacağını belirtiliyor. İşyerlerinin reklam sayesinde tanınabileceğini de dillendiriyor.

Söylemsel yargi:

- Reklamlar bir çok işyerini tanıma imkanı verir.

- Reklam (1969, İstanbul)

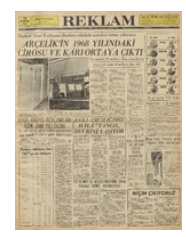

Söylemsel yüzey: Reklam gazetesinin 20 cümlelik kısa sunuşu 'Niçin Çıkıyoruz' başlığı taşıyor ve Türkiye'de reklamın verimsiz olduğu, tahminlere dayandığı, dolayısıyla reklam harcamalarının israf edildiği, Batı'da ise reklama eldeki bilgilerden hareketle yatırılan her kuruşun karşılığının alındığı vurgusuyla başlıyor. İsrafın maliyeti artırdığı belirtilerek gazetenin ekonomi ve piyasaya yaklaşım amacını betimliyor.

Söylemsel yargi:

- Reklam Türkiye'de verimsizdir.

- Reklam harcamaları Türkiye'de israf edilmektedir. 
- Reklam harcamaları tahminler üzerinden yapılır.

- Batı ülkeleri temel bilgiden hareket ederek yaptıkları reklam harcamalarının karşılığını alır.

- Reklam 20 (1974, İzmir)

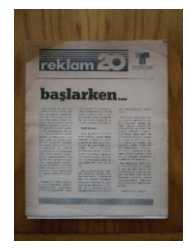

Söylemsel yüzey: Reklam 20 gazetesinin bir sayfalık sunuş yazısı 'Başlarken' başlığı taşıyor ve önce reklamın pazarlamanın bir dalı olduğunu, bir sanayi olduğunu, reklam ajanslarının milli gelirden hatırı sayılır bir pay aldıklarını, bu durumun Türkiye'yi de olumlu yönde etkilediğini vurguluyor. Reklamcılık ile ilancılığın kısa süre öncesine dek karıştırıldığını, reklamcılığın pazarlamacılıkla doğru orantılı olarak bir hizmet sektörü biçiminde ortaya çıkması gerektiğini belirtiyor. İstanbul'daki reklam ajanslarının aralarındaki rekabetin, alınan komisyonlardan indirim yapma yerine daha iyi hizmet sunma şekline evrildiğini ifade ediyor. İzmir reklam piyasasının İstanbul piyasasına giden işler yüzünden yavaş geliştiğini ama daha iyi hizmet bağlamında önemli bir değişim yaşandığını da dillendiriyor.

\section{Söylemsel yargı:}

- Reklam pazarlamanın bir dalıdır.

- Reklam bir sanayidir.

- Reklam ajansları Batı'da milli gelirden pay alırlar ve Türkiye bundan olumlu yönde etkilenmiștir.

- Reklamcılık ve ilancılık artık birbirine karıștırılmıyor.

- Reklamcılık artık pazarlama gibi bir sektör haline gelmelidir.

- Reklamcılar arasındaki rekabet, artık komisyon indirimlerinde değil, daha iyi hizmet üretmeye dönük olarak gerçekleşmektedir.

- İzmir reklam piyasası, daha iyi hizmet noktasında artık İstanbul'u yakalamıștır.

Bütünce kapsamına aldığımız reklam dergi-gazetelerinin her birini, belirlediğimiz yöntemsel basamaklardan, bir başka deyişle iki düzeyli yalın bir çözümleme işleminden geçirdikten sonra toplu bir nihai okumaya geçebilir ve sonuçta, buraya dek oluşturulan veri demetinden hareketle bir çıkarsamaya varabiliriz.

\section{Sonuç}

Reklamın bir dönemini okuyabilmek ve dönemin reklama bakışını belirleyebilmek için önce müracaat ettiğimiz reklam gazete-dergileri konusunda kısa bir bilgi edindik, ardından yöntemimizden söz ettik ve çözümleme işlemini gerçekleştirdik. Çözümleme işlemi süresince, erişilebilir durumdaki on reklam gazete-dergisindeki sunuş yazılarının söylemsel yüzeyinden hareketle söylemsel yargıyı her sunuş için ayrı ayrı belirlemeye ve anlamlamaya çalıştık. Sonrasında söylemsel yargıları bir araya getirerek harmanlayınca, yirminci yüzyılın üçüncü çeyreğine denk gelen, reklamın reklam dergi ve gazetelerindeki dönemsel görünümü belirginleşmiş oldu. Bu yapılırken, çözümleme sürecinde ortaya çıkan benzeşik söylemsel yargılar söz uzatımını engellemek ve duru bir çıkarsama elde edebilmek için elendi. Karşıtsallığı içkin verileri topluca okuyup anlamlamaya çalışırken, 
reklam gazete ve dergilerinin sunuşlarında reklama dönük üretilmiş kimi yargıların, gazete ve dergilerin hedef kitlelerine yönelik olarak üretilmiş olabileceğini de bir öngerçek olarak hatırda tutmakta yarar var.

Sunuş metinleri biçimsel kurgusu itibariyle beş cümlelik oldukça kısa metinler olabildiği gibi bir sayfalık ya da bir sayfayı aşan uzunlukta metinler olabilmektedir. Metinlerin söylemsel yüzeyleri çıkarken ya da niçin çıkıyoruz gibi bir başlıkla başlamakta, kimi zaman muhterem okurlarımız gibi bir alt başlıkla devam etmekte; çıkış amacı, reklama bakış tarzı, okura hizmet şekli ya da okuyucudan beklentiler ilerleyen paragraflarda betimlenmektedir. Başlangıçta olduğu gibi saygı ve şükran hitapları eşliğinde, genellikle gazete-derginin ya da sahibinin ismini taşıyan bir imza ile sonlanırlar.

Reklamın, reklam dergi-gazetelerin söylemsel yüzeyinden okunan söylemsel yargllar derlendiğinde ortaya çıkan görünümünü ve söylemsel çıkarsamaları şöyle ifade etmek mümkündür:

- Hemen her gazete-derginin reklamın önemine yaptığı vurgu, onun kuşkusuz son derece önemli bir ticari iletişim faaliyeti olduğunun teslimi niteliğindedir ve henüz öneminin altı çizilme ihtiyacı duyulmakta olduğu açıktır.

- 'Reklamın öneminde şek şüphe yoktur. Reklamın önemine dair geçmiş dönemlerden kalma mütereddit tutumlar tez zamanda aşılmalı, önemi tekrar tekrar vurgulanarak geniş kitlelere anlatılmalı, ilkel durumundan kurtarılmalıdır' şeklinde ortaya çıkan yargı, reklamın öneminin savaş sonrasında hala telaffuz edilmek zorunda kalındığını ve onun aslında özellikle reklamverenlerce tam olarak anlaşılamadığını gösterir.

- Reklamın ülkeleri refaha götüreceği, ticari, iktisadi, sınai ilerlemeye ya da kalkınma için önemli olduğu, ürünlerin piyasaya sunulabilmesi, satılabilmesi, talebin artması ve piyasa rekabeti için gerekli olduğu yargısı, reklamın henüz tam olarak anlaşılmamış olduğunun, kavramsallaștırılmasında olası eksiltiler bulunduğunun ve eksiltileri sürekli anlatarak giderme çabası gösterildiğinin teyidi niteliğindedir.

- Reklamverenin geniş kitlelere ulaşmak üzere reklam yayını yapması gerektiği, yayın kuruluşlarının işletmelere reklam hizmeti ulaştırılabilmesi için işletmelerin reklam verme kararlılığı göstermeleri gerektiği, kısacası reklamverenin reklamvermesinin kaçınılmaz olduğu yargısı, reklamverenin henüz reklam verme konusunda teşvik ve eğitime muhtaç olduğuna, reklam verme konusunda bilinçlendirilmesi gerektiğine gönderme yapmaktadır.

- Reklamın Türkiye'de verimsiz olduğunu, reklam harcamalarının israf edildiğini, tahminlere dayalı olarak yapılan reklam harcamalarının kuşkusuz karşılığının alınamadığını ifade eden yargılar, reklam harcamalarının henüz bilinçsizce ve el yordamıyla yapıldığını, harcamaların doğal olarak israfa neden olduğunu betimleyicidir.

- Reklam ile sanatın birbirinden ayrı düşünülemeyeceği, sanatın da sanatçının da reklama ihtiyaç duyduğu, ama bunun eleştirmenler marifetiyle yapılması gerektiği, eleştimenlerin görevinin iyi eserlerin reklamını yapmak olduğu gibi bir yargı, sanatın reklam ile ilişkisini keşfeden bir yargıyı içkin olmasına karşın reklam ile bugün iletişim yönetimine doğrudan nispet eden halkla ilişkilerin henüz ayrışmadığını, hatta bugün meşru görülmeyecek türden eleştirmene örtülü reklam yapma misyonu yüklendiğini göstermektedir. Ama aynı zamanda sanat gibi birçok alanda reklama ihtiyaç duyulduğunun ancak nasıl olacağı konusunda ortada fazlaca bir fikir olmadığını da gösterir.

- Reklamın işyerinin şöhret ve/ya da tanınmışlığı artıracağı, insanları ve milletleri 
birbirine yakınlaştıracağı, ülke aleyhine yapılan olumsuz propagandaları engelleyeceği yargısından, neredeyse iletişim yönetimine ilişkin tüm alanları reklama yükleme biçiminde bir kavramlaştırmanın yapıldığı anlaşılmaktadır. Reklam bir yandan yüceltilirken, öbür yandan ona taşıyamayacağı devasa bir kavramsal alan inşa edildiği görülmektedir.

- Reklam ve propagandanın girișimcinin başarısında büyük pay sahibi olduğu ama yine de ona bir ihtiyaç gözüyle bakılmadığı, boşa bir masraf/harcama kalemi olduğu, tersine görüşler olarak bu kez reklam ve propaganda harcamalarının gereksiz olmadığı, reklam ve propagandanın ürün ve hizmeti değerli hale getirdiği, ayrıca reklamın pazarlama ile ilişkilendirildiği, onun pazarlamanın bir dalı olduğu gibi ifadelerle şekillenen yargı, reklamın artık ilancılık kavramından iyiden iyiye uzaklaşmaya çalıştığı bir dönemde ${ }^{4}$ bu kez propaganda ya da pazarlama gibi iletişim bileşenlerinin içinden kurtulamadığını göstermektedir. Reklamın propaganda ya da pazarlama ile eşleştirilmesi, reklamın öneminin kavranması ile kavramsallaştırılması arasındaki derin uçurumu ifade eder.

- Reklamın kimi zaman bir sanayi olarak değerlendirilmesi, ilancılıktan giderek uzaklaşan ve kendi içinde bir sektör haline gelmeye başlayan reklamın artık iyi hizmet üretme esasına dayandığını, kalkınma hamlelerinde etkin rol oynadığını, İstanbul gibi kimi büyük şehirlerde de daha iyi hizmet ilkesiyle sektörleştiğini tanımlayıcıdır. Reklamın Batı'da olduğu gibi milli gelirden pay alabileceğinin telaffuz edilmesi de onun artık yavaş yavaş sektörleştiğinin teyidi niteliğindedir.

Çözümleme sürecinde mümbit çıkarsamalar yapma imkanı veren sunuş yazılarının, reklam dergi-gazetelerinin reklama yaklaşım biçimlerini özetleyen metinler olarak kimi sert bir manifesto, kimi salt bir açıklama, kimi mütevazi bir çıkış beyanı, kimi heyecanlı bir katkı, kimi güçlü ya da özgüvenli bir uyarı niteliğinde ama hepsi reklamın dönemsel durumunun betimsel görünümünü kendi ölçüsünde verebilecek kabiliyette olduğu görülmüştür. Çözümlemenin öncesinde dillendirilen sunuş yazılarından hareketle dönemin okunabileceği öngörüsü test edilmiş, söylemsel yargılar marifetiyle dönemsel veri elde edilerek öngörü doğrulanmıștır.

Sunuş yazılarının söylemsel yargılarından hareketle, savaş sonrasında Türkiye'de reklamın artık geçerli ve benimsenmiş ancak kendisi için kavramsallaştırılmamış olduğu ve diğer iletişim bileşenleriyle birlikte düşünüldüğü kolaylıkla söylenebilir. Yirminci yüzyılın ikinci yarısı reklamın olgunlaşma dönemini belirginleştiren bir deneyim olarak reklamın Türkiye'deki gelişim serüveninde modern reklamcılığın temellerinin atıldığı zor bir dönem olarak kaydedilebilir. Savaş sonrası dönemin reklam için çaba, arayış ve yaklaşımlarının bugün neredeyse hiç söz konusu olmayacağı kuşkusuz öngörülebilirdir. Reklamın varoluşsal boyutları bugün o dönemin yaklaşımlarının çok ötesinde olarak dijital çağdaki varoluş sorunlarıyla yoğrulmaktadır. Olgunlaşma döneminin birikim ve deneyimi olmasaydı, bugünkü çağın dijital rekabetine ayak uydurmakta daha da çok zorlanırdı.

Son tahlilde, reklama dönük olarak burada serdedilen bütüncül bakış ve farklı yaklaşımlar, reklamın iyice anlaşılma ve olgunlaşma dönemini betimleyicidir. Reklamı anlama, anlatma ve kimliğini betimleme çabasının, yüzyılın üçüncü çeyreğinde henüz yoğun biçimde devam ettiği görülmektedir. 


\section{Notlar}

1 17. yüzyılın sonları ve 18. yüzyılın başlarında yapııdığı tahmin edilen ilk reklam bir mide ilacı olan Altınbaş Tiryakı reklamıdır. (Bu konuda daha ayrıntılı bilgi için bkz. Eldem, 1994, s.13-16).

2 Konuların sunuluşunda Avrupa modeli devam ettirilmekle birlikte Amerika'da çok daha dinamik bir modelin var olduğu fark edilmiştir”. (Koloğlu, 1999, s.127). Ayrıca Reklamda Amerikan etkisinin izlerini ilk reklam kitabında da kolaylıkla görmek mümkündür. (Çamdereli, 2013, s.56-65)

3 Yirminci yüzyılın üçüncü çeyreği iktisadi, ticari, siyasi ve sosyolojik olarak çetin bir dönemi ifade ediyordu. 50'li yıllara gelirken, dünya savaşın travmalarını atlatmaya ve yaralarını sarmaya çalışırken, Türkiye de uyguladığı savaş ekonomisinden yeterince yorgun düşmüş olarak yeni hamleler arayışındaydı. Bir yandan kalkınma hamleleri planlanıyor bir yandan vergi kanunlarıyla ekonomiye şekil verilmeye çalışılıyordu. Öte yanda, siyasal kültür dinamikleri değişiyor, demokratikleşme sürecine adım atııyor, ekonomide liberalleşme sürecine tanıklık ediliyor, Marshall yardımıyla tanışııyordu. Tarıma dayalı sanayileşme yerini serbest dış ticaret rejimine bırakıyordu. "1954 yılından itibaren gerek dış ticarette gerek tarım sektöründe meydana gelen tıkanmalar sonucunda tarıma ve dış ticarete dayalı sanayileşme politikası terk edilerek, yerine sanayileşmeye öncelik veren korumacı, ithal ikamesine yönelik politikalar tercih edilmiştir. Türkiye bu dönemden itibaren iç pazara yönelik, tüketim malları üretimini ön plana çıkaran bir ithal ikameci sanayileşme sürecinde yol almaya başlamıştı". (Kanca, 2012, s.60). 60'lı yıllar serbest piyasa ekonomisinden uzaklaşıldığı, denetimli planlı ekonomiye geçildiği, beş yıllık kalkınma planlarının 70'li yılların ortalarına dek yürürlükte kaldığı yıllardır. (Ayrıntılı bilgi için bkz. Eraslan, 2021). Ayrıca, çeyrek yüzyılın, aynı zamanda biri darbe biri muhtıra olmak üzere iki askeri müdahaleye de tanıklık ettiği ve bunun ekonomi başta olmak üzere bütün yaşam alanlarını derinden etkilediği de anılmak değerindedir.

4 Reklamın terim olarak farkedilişi 1880'lere dek uzanır (Koloğlu, 1999, s.118-127); Ayrıca, reklam teriminin yüzyılın başında tek tük görülmeye başlanması ilan teriminin 1930'lara dek kullanımda kalmasını engellemez. Reklamın ilan ile yollarının iyiden iyiye ayrılmaya başlaması içinse 50'li yılların gelmesi gerekmiştir. Dikkat edilirse ilan ve reklam terimleri bir gazeteye birlikte isim olabiliyor, birlikte eşdeğerli olarak kullanılabiliyor, ama bir yandan da artık ilan toplama ile reklam üretme aynı karşılıkları oluşturmamaya başlıyor. İlan ile reklam teriminin Türkçedeki kullanım serüveni oldukça ilginçtir. (bu konuda ayrıntılı bilgi için bkz. Çamdereli, 2013, s.66-73).

\section{Kaynakça}

Çamdereli, M. (2013). Reklamın görme dediği içinde. İstanbul: Avrupa Yakası Yayınları.

Çamdereli, M., Varlı, M. (2009). Reklam dergi ve gazeteleri. İstanbul: Rasyo Yayınları.

Eldem, E. (1994). “Bir ilaç reklamı üzerine, Venedik’ten ithal Altınbaş Tiryakı”. Toplumsal Tarih, Sayı 2.

Eraslan C. (2021). “9. 1950’den günümüze Türkiye ekonomisi Ve Türk iktisat politikaları”, Atatürk İlkeleri Ve İnkilap Tarihi-II İçinde, https://cdn-acikogretim. istanbul.edu.tr/auzefcontent/19_20_Bahar/ataturk_ilkeleri_ve_inkilap_ tarihi_2/9/index.html.

Evre, B. (2009). "Söylem analizine yönelik farklı yaklaşımlar: bir sınıflandırma girişimi", İsmet Parlak (der.), Medyada Gerçekliğin İnşası: Türk Medya Söylemine Eleștirel Bir Bakış içinde. Konya: Çizgi Kitabevi.

Kanca, O. C. (2012). “1950-1960 arası Türkiye'de uygulanan sosyo-ekonomik politikalar”, Mustafa Kemal Üniversitesi Sosyal Bilimler Enstitüsü Dergisi, Cilt 9, Sayı 19

Koloğlu, O. (1999). Reklamcılığımızın ilk yüzyılı. İstanbul: Reklamcılar Derneği Yayınları.

Rifat, M. (1998), XX. Yüzyılın dilbilim ve göstergebilim kuramları. İstanbul: Yapı Kredi Yayınları. Cilt 2.

Yücel, T. (1999), Söylemlerin içinden. İstanbul: Yapı Kredi Yayınları. 


\title{
An Inside Look at The Advertisement
}

\author{
Mete Çamdereli (Prof. Dr.)
}

\section{Extended Abstract}

Readings on the history of advertising gives information and idea into many subjects and periods, ranging from social changes to economic parameters, in a spectrum based on communication. The purpose of this study is to reveal whether the written about the advertising will allow the period reading as a document. To understand this, we look at the newspaper and magazine advertising in Turkey, and only focused their presentations in writing.

We have selected 10 advertising newspapers and magazines, spanning a quarter century and whose first issues are accessible, as the object of study.

We have thus limited our work, as a time span, the years 1948-1974, so to speak, to the early post-war period. Within the framework of this purpose, scope and limitation, it is predictable that by reading the presentation articles in the first issues of advertisement newspapers, the discourse of the period and the understanding of advertising of the period will be revealed.

In order to be able to read a period of the advertisement and determine the advertisement perspective of the period, we first obtained a brief information about the advertising newspapers-magazines that we applied, then talked about our method and carried out the analysis process. During the analysis process, we tried to determine and understand the discursive judgement separately for each presentation text, based on the discursive surface of the presentation articles in 10 accessible advertising newspapers-magazines. Then we brought together discursive judgments and blended them. Eventually, corresponding to the third quarter of the twentieth century, the periodic appearance of the advertisement in the advertising magazines and newspapers became clear.

It is possible to express the appearance and discursive inferences that emerge when the discursive judgements read from the discursive surface of advertising magazines and newspapers are compiled as follows:

- The emphasis that almost every newspaper-magazine puts on the importance of advertising is a sign that it is undoubtedly an extremely important commercial communication activity, and it is clear that still its importance needs to be underlined.

- The judgement of "There is no doubt about the importance of advertising, hesitant attitudes from past periods regarding the importance of advertising should be overcome in a short time and its importance should be explained to the masses by emphasizing its importance over and over, and it should be rescued from its primitive state" shows that the importance of advertising still has to be pronounced after the war and it is not fully understood especially by advertisers.

- The judgement that advertising will lead countries to prosperity, that it is important for commercial, economic, industrial progress or development, that it is necessary for the introduction of products to the market, their ability to sell, increase in demand and market competition is a confirmation that the advertisement has not been fully 
understood yet, that there are possible decreases in its conceptualization, and that efforts are made to overcome the decreases by constantly explaining.

- The judgement that the advertiser should broadcast advertisements in order to reach large audiences and that the broadcasting companies should show the determination to advertise in order to provide advertising services to the enterprises, in short, the advertiser is inevitable to advertise shows the fact that the advertiser still be in need of incentives and training in advertising and they should be made aware of advertising.

- The judgements that the advertising is inefficient in Turkey, that has been wasted advertising expenditure, advertising expenditures made based on estimates cannot be compensated expresses that advertising expenditure is still unconscious and it is causing natural wastage of expenditure.

- The judgement that "advertising and art cannot be considered separately from each other, that both art and artists need advertising, but this should be done by the help of critics, that the duty of critics is to advertise good works" shows that advertising and communication management have not yet been separated, and it even shows that the critic has the mission of making covert advertising which is not deemed legitimate today. But it also shows that advertising is needed in many fields such as art but there is not much idea about how it will be.

- From the judgment that advertising will increase fame and / or recognition of the workplace, bring people and nations closer together, and prevent negative propaganda against the country, it can be seen that a conceptualization has been made in the form of uploading almost all areas of communication management to advertising. While the advertisement was glorified, on the other hand, a huge conceptual space that it could not carry was built into it.

- The judgment that "The advertising and propaganda play a major role in the success of the entrepreneur, but it is still not regarded as a need, it is a wasted expense / expenditure item, on the contrary, advertising and propaganda expenditures are not unnecessary, that advertising and propaganda make the product and service valuable, also it is associated with marketing and that it is a branch of marketing" shows that advertising could not get rid of communication components such as propaganda or marketing in a period when advertising is trying to move away from the concept of advertising. Matching advertising with propaganda or marketing expresses the deep gulf between understanding the importance of advertising and its conceptualization.

- The fact that advertising is sometimes evaluated as an industry defines that advertising, which has gradually moved away from advertising and started to become a sector in itself, is based on the principle of producing good services, plays an active role in development moves, and it has become a sector with the principle of better service in some big cities such as Istanbul. The fact that the advertisement can get a share from the national income as in the West is a confirmation that it is gradually becoming a sector. 
It appears from the judgment of discursive presentation text, advertising is not yet conceptualized but it is valid and adopted in Turkey after the war, and it is easy to say that advertising considered together with other communication components. The second half of the twentieth century in Turkey can be recorded as a difficult period that advertising has strengthened the foundation of modern advertising creative maturation period in the development.

Keywords: Advertisement History, Advertisement Newspaper, Term Between 19481974, Advertisement Analysis.

Bu makale intihal tespit yazııımlarıyla taranmıştır. Intihal tespit edilmemiştir.

This article has been scanned by plagiarism detection softwares. No plagiarism detected.

Bu çalışmada "Yükseköğretim Kurumları Bilimsel Araştırma ve Yayın Etiği Yönergesi" kapsamında uyulması belirtilen kurallara uyulmuştur.

In this study, the rules stated in the "Higher Education Institutions Scientific Research and Publication Ethics Directive" were followed.

Araştırma tek bir yazar tarafından yürütülmüştür.

The research was conducted by a single author.

Çalışma kapsamında herhangi bir kurum veya kişi ile çıkar çatışması bulunmamaktadır.

There is no conflict of interest with any institution or person within the scope of the study. 